Article

\title{
Public Design of Urban Sprawl: Governments and the Extension of the Urban Fabric in Flanders and the Netherlands
}

\author{
Edwin Buitelaar ${ }^{1,2, *}$ and Hans Leinfelder ${ }^{3}$ \\ ${ }^{1}$ PBL-Netherlands Environmental Assessment Agency, 2594 AV The Hague, The Netherlands; \\ E-Mail: edwin.buitelaar@pbl.nl \\ 2 Department of Human Geography and Spatial Planning, Utrecht University, 3584 CB Utrecht, The Netherlands \\ ${ }^{3}$ Department of Architecture, KU Leuven, 9000 Gent, Belgium; E-Mail: hans.leinfelder@kuleuven.be \\ * Corresponding author
}

Submitted: 28 November 2019 | Accepted: 6 February 2020 | Published: 6 March 2020

\begin{abstract}
Urban sprawl is often portrayed as a (quasi-)natural process, as inevitable and taking place behind our backs. However, we claim that it is co-produced by government: Governments not only allow sprawl to happen, but often also incentivise and stimulate it, either knowingly or unintentionally. We substantiate this claim by comparing urban development and government institutions in Flanders (Belgium) to the Netherlands, two neighbouring territories, yet very different regarding this matter. Urban development in the Netherlands is considered orderly and compact, whereas in Flanders it is considered haphazard and sprawled. Urban planning, too, could not be more different. Strong national planning and an active local land policy characterise Dutch planning, while the opposite applies to Flanders. Although these images seem largely accurate, we argue that it is very particular government institutions in both countries that (help) create and reproduce the various degrees of urban sprawl.
\end{abstract}

\section{Keywords}

discourses; Flanders; government institutions; land-use planning; public design; the Netherlands; urban development; urban fabric; urban sprawl

\section{Issue}

This article is part of the issue "Comparative Planning, Learning and Evolving Governance" edited by Kristof Van Assche (University of Alberta, Canada), Raoul Beunen (Open University of the Netherlands, The Netherlands) and Stefan Verweij (University of Groningen, The Netherlands).

(C) 2020 by the authors; licensee Cogitatio (Lisbon, Portugal). This article is licensed under a Creative Commons Attribution 4.0 International License (CC BY).

\section{Introduction}

The word "sprawl" in relation to cities was first coined in the United States by Earle Draper. It was conceived to describe the outward movement of low-density urban development. The term especially points to negative economic effects in terms of long and expensive travelling, and social disadvantages, most notably the loss of community life (Nechyba \& Walsh, 2004). More recently, the issue has been picked up more widely in Europe, where the area of land that has been developed continues to grow in all countries at a far greater pace than the increase in population (Henning et al., 2016; Uhel, 2006).
In the developing world, especially in Africa and Asia, it manifests itself in a competing demand for areas suitable for agriculture and areas suitable for urban development (Montgomery, 2008).

Urban sprawl is often portrayed as an uncontrolled (Resnik, 2010) and unplanned (Oueslati, Alvanides, \& Garrod, 2015; Uhel, 2006) process: Individual preferences, the increasingly intensive use of automobiles, and market dynamics are generally considered to be the main causes of sprawl development in a situation of presumed deregulation and absence of planning (Moroni \& Minola, 2019). As a result, many argue that more (comprehensive) planning and regulation are the solution to stop 
sprawl and its damaging role (Ewing, 1997; Ewing \& Hamidi, 2015; Morriss \& Meiners, 2000).

This article takes a critical stance against this common analysis of urban sprawl. Not only do governments often not constrain sprawl, but there are also many instances in which they actually co-create or foster it. This idea-that greater liability for sprawl should be assigned to public authorities, creating unfavourable conditions for densification and favourable conditions for dispersed development-has not been advanced by too many scholars (exceptions include, e.g., Lewyn, 2005; Moroni \& Minola, 2019; Pendall, 1999; Tennekes, Harbers, \& Buitelaar, 2015). The critical contributions that do exist, however, seem to only focus on specific government institutions (such as "growth controls"), and/or are derived inductively and rather descriptively (i.e., not conceptually embedded) from one specific national context, and therefore do not necessarily apply elsewhere.

Starting from these context-specific contributions on urban sprawl, the main aim of this article is to introduce a conceptual framework for tracing "sprawl-producing" (as opposed to the well-known "sprawl-controlling") government institutions that can be applied in different contexts. This framework is embedded within neoinstitutional insights, particularly "discursive institutionalism" (e.g., Arts, van Tatenhove, \& Leroy, 2000; Hajer, 1995). The applicability of the conceptual framework is also tested by comparing two neighbouring countries with very different urban patterns and institutional contexts: the Netherlands and Flanders (actually, a region of Belgium). Using the framework, institutional differences and similarities were detected that allow reflecting on how government institutions enable or constrain urban sprawl.

The article is structured as follows: Section 2 starts with a (non-exhaustive) review of the literature on sprawl. In addition, the literature on the relationship between institutions is explored on the one hand and urban development on the other, which helps to develop a conceptual framework for analysing government institutions in relation to urban sprawl within different national-institutional contexts. That framework is then applied, in Section 3, to urban sprawl in Flanders and the Netherlands. In Section 4, conclusions are drawn from the conceptual and empirical analysis. The article ends with a discussion (Section 5) about current and future urban development in the Netherlands and Flanders and with a discussion about international comparative research, the central theme of this thematic issue.

\section{The Institutional Origins of Urban Sprawl: A Conceptual Framework}

\subsection{Urban Sprawl}

In general, the literature on urban sprawl refers to the excessive spatial growth of cities (Brueckner, 2000). A North American perspective defines sprawl as a "low- density, automobile-dependent, exclusionary new development on the fringe of settled areas often surrounding a deteriorating city" (Squires, 2002, p. 2). A more European definition, by the European Environment Agency (EEA), describes the "physical pattern of lowdensity expansion of large urban areas, under market conditions, mainly into the surrounding agricultural areas....Development is patchy, scattered and strung out, with a tendency for discontinuity" (Uhel, 2006, p. 6). These descriptions refer to sprawl as a suburbanisation process related to the outward growth of cities. In a more recent report of the EEA, the relation between sprawl and the growth of cities is less explicit: "A landscape [is affected by urban sprawl] if it is permeated by urban development or solitary buildings and when land uptake per inhabitant or job is high" (Henning et al., 2016, p. 22). They consider sprawl not so much in terms of the rural (more or less) transforming into the urban because of the gradual expansion of the latter, but as an urbanisation process in situ of the land, bringing together two opposites (urban and rural) in one conception. Similar observations have been made by Gheysen, Scheerlinck, and van Daele (2017), Neutelings (1991), Sieverts (1999), and Vigano, Arnsperiger, Barcelloni Corte, Cogato-Lanza, and Cavalieri (2017), among others, who named it, respectively, "all city/all land," "patchwork metropolis," "Zwischenstadt" and "horizontal metropolis."

In general, the majority of academic publications on urban sprawl roughly address one, or a combination, of the following four topics: the measurement of sprawl, the causes, the effects and the (potential) policy measures.

\subsubsection{Measurement}

Based on different conceptions of sprawl, different indexes of sprawl have been produced and applied empirically, often in GIS applications, for cities all over the world (see, for instance, Frenkel \& Ashkenazi, 2008; Galster et al., 2001; Henning et al., 2016; Oueslati et al., 2015). These indexes are often determined by variables related to income, demographics, agricultural land value, transportation, political and other socio-economic, climatic and geophysical elements. The indexes mainly attempt to represent sprawl as an increase of the spatial scale and dispersion of the (monocentric) city and an increase of dispersion accompanied by a decrease in density (Ewing, Pendall, \& Chen, 2002; Hamidi, Ewing, Preuss, \& Dodds, 2015). Jaeger, Bertiller, Schwick, and Kienast (2010), for instance, relate urban sprawl to both the amount of land taken for urban use and the degree of dispersion of that urban land uptake:

Urban sprawl is visually perceptible. A landscape suffers from urban sprawl if it is permeated by urban development or solitary buildings. For a given total amount of build-up area, the degree of urban sprawl will depend on how strongly clumped or dispersed the 
patches of urban area and buildings are; the lowest degree of sprawl corresponds to the situation when all urban area is clumped together into the shape of a circle. The highest possible degree of sprawl is assumed in an area that is completely built over. Therefore, the more urban area present in a landscape and the more dispersed the urban patches, the higher the degree of urban sprawl. (Jaeger et al., 2010, p. 400)

To illustrate the two dimensions of sprawl: a territory that has $10 \%$ of urban land is less "sprawled" than one that has $20 \%$ of its land in urban use. And a territory in which this $20 \%$ is shaped as one consolidated circle is less sprawled than when that $20 \%$ has the form of many smaller separated dots.

\subsubsection{Causes}

According to Brueckner (2000), three market failures should be held responsible for excessive urban sprawl: the failure to take into account the social value of open space when land is converted to urban use, the failure of individual commuters to recognise the social costs of traffic congestion, and the failure of real estate developers to take into account all of the public infrastructure costs because of their development projects. A lot of the drivers of urban sprawl that are addressed by other scholars can be directly or indirectly related to these market failures (see, for instance, Colsaet, Laurans, \& Levrel, 2018; Ewing, 1997; Henning et al., 2016; Uhel, 2006).

\subsubsection{Effects}

An extensive review of the literature on the effects of urban sprawl has been produced by Henning et al. (2016) as part of a report for the EEA on urban sprawl in Europe. They consider a large number of environmental aspects, including effects on hygiene, landscape and flora and fauna, economic aspects such as traffic congestion costs, public service costs and the loss of tourist and residential attractiveness, and finally, social and quality of life aspects, including segregation and health problems. The more than 60 effects mentioned in the report illustrate the vast impact of urban sprawl on the daily functioning of societies all over the world. Only a few scholars (Gordon \& Richardson, 2000; Kahn, 2001) see the benefits of sprawl, such as more and cheaper housing and more job options.

\subsubsection{Policies}

As the lack of central ownership or planning and highly fragmented land-use governance are defined as important political drivers of urban sprawl (Ewing et al., 2002), changes in policies are consequently expected to contribute to the reduction of sprawl. A lot of faith is put into active planning in the form of urban growth manage- ment through zoning and urban boundaries in order to correct for the failures of the market. Additionally, there is an increasing awareness that adequate decisions on urban growth cannot be made solely at the local level: local regulations generally tend to promote sprawl but can also, when aiming to reduce sprawl, have negative spill-overs to municipalities that do not regulate growth (Anthony, 2004; Uhel, 2006).

\subsection{The Role of Institutions}

Urban sprawl is created by people, but these people do not act within a vacuum; they act within-and interact with-an institutional framework that guides the spatial development of a territory. Institutions are the rules of the game, whether formal and written down or unwritten and informal, that shape human interaction (North, 1990). There has been much consideration for institutions in the urban planning literature and the wider social sciences (e.g., Alexander, 2005; Buitelaar, Lagendijk, \& Jacobs, 2007; Hall \& Taylor, 1996; March \& Olsen, 1989; North, 1990).

Government institutions may foster urban sprawl (e.g., Lewyn, 2005; Pendall, 1999; Tennekes et al., 2015). When we say this, we do not intend to say that the government is solely responsible and there is no role of "the market" or of private actors. On the contrary, there would be no sprawl without private initiators who want to develop and live further away from the urban centre. But government institutions impact the size and direction sprawl may take. Or as Lindblom (2001, p. 42) puts it: "If the market system is a dance, the state provides the dance floor and the orchestra." In other words, the former cannot exist without the latter; to consider "government" and "the market" as antagonists is misleading, even an oxymoron (Alexander, 2001; Buitelaar, 2003). In this article, we focus on what we call "government institutions," which we consider to be the formal or informal rules (co)produced and reproduced by government agencies in order to guide society (and the market).

Moroni and Minola (2019) acknowledge the (public) institutional origins of urban sprawl and come up with seven government issues/institutions that have contributed to urban sprawl in Italy: (1) an enduring "antiurban" planning culture; (2) a priori ostracism of certain activities (i.e., certain activities not being allowed in the city and therefore pushed out); (3) regulations that hamper urban compactness; (4) obstacles to urban re-use and regeneration; (5) infrastructure policies (i.e., urban can and will only move outwards if facilitated by infrastructure and utilities provided under conditions of public monopoly); (6) property taxes; and (7) local political fragmentation (i.e., competition among municipalities leading to negative policy externalities in the form of spatial inefficiencies).

We confirm that these elements are very important and helpful in trying to trace the institutional origins of urban sprawl in other countries. But we also see two lim- 
itations. First, the seven issues seem to be derived inductively, from Italian practice, and not from a comprehensive, theory-based conceptual framework that allows for replication in other contexts. Various relevant Dutch and Flemish institutions (e.g., active land policy, housing subsidies) do not fit under any of the seven labels. Next, by listing the seven issues on a flat list, no differentiation is made. More precisely, no account is taken of their ontological differences.

Based on the nature of Moroni and Minola's seven issues and our exploration of discursive-institutional literature, a major and more conceptual distinction should be made between discourses (issue 1) and institutions (issues 2 to 6; Arts et al., 2000; Hajer, 1995; Schmidt, 2010). These are broad concepts that need to be operationalised for the issue under investigation (i.e., the stimulating role of government in the process of urban sprawl).

A discourse is a "specific ensemble of ideas, concepts and categorisations that are produced, reproduced and transformed in a particular set of practices and through which meaning is given to physical and social relations" (Hajer, 1995, p. 44). The concept of institutions, on the other hand, is very broad and needs a certain customisation and categorisation in the context of government institutions and urban sprawl. That is why we suggest categorising government-created institutions with regard to the development of land and real estate in terms of how they intervene in the land market. Governments may be active, by buying and developing land and real estate, passive, by regulating land use, and persuasive, by trying to incentivise particular land uses (see Needham, Buitelaar, \& Hartmann, 2018). These three broad categories can be further subdivided into an active government provision of (1) land for public goods, such as infrastructure, or (2) land for private goods, such as housing, into a passive regulation of land use through (1) locationspecific or (2) more generic rules, and into persuasion through the incentivisation of land use via (1) taxes or (2) subsidies.

Finally, since governing urban development is a multilevel and multi-agency activity, this implies that multiple discourses and institutions are generated by multiple public and private actors at different territorial scales. Self-evidently, these actors operate alongside one another, either complementary to or in competition with each other. Moroni and Minola (2019) refer, for instance, to the competition between municipalities for new housing developments in order to increase local tax revenues. Later in this article we will address passive locationgeneric regulations that stimulate urban sprawl. Often, these have emerged as the result of bottom-up processes in which local politicians signal legal obstacles for individual housing development to the national legislator. In other words, we acknowledge that the interplay between various (competing) discourses and institutions is very relevant, but for the sake of reduction, we have decided to focus on government discourses and institutions only.

\section{The Institutional Origins of Urban Sprawl in Flanders and the Netherlands Compared}

In this section, we apply the conceptual framework outlined above to urban sprawl and government institutions in Flanders and the Netherlands. We use secondary sources (i.e., academic literature and policy reports) for making the comparison. In addition, we focus roughly on the second half of the twentieth century (1950-2000). This is the period in which spatial planning institutionalised and matured most strongly in both countries. More recent developments (since the turn of the century) get less attention as their impact is less clear. Our analysis is a non-exhaustive treatment that serves to illustrate how government institutions enable rather than constrain sprawl. We start by pointing out the overall post-war discourse towards the concentration of urbanisation (Section 3.1) before moving to specific institutions (Section 3.2).

\subsection{Discourses about Urbanisation}

Moroni and Minola (2019) qualify the Italian discourse as anti-urban. We like to propose a continuum of discourses in relation to the degree of concentration of urbanisation, with pro-dispersion on one end of the spectrum and pro-concentration on the other. Although it is hard to precisely measure discourses according to this scale, we observe (based on a literature review) clear differences in the ambitions of urban planning policy in both regions. Planning policy in the Netherlands can be qualified as more pro-concentration, albeit in a polycentric rather than a monocentric way, while the Flemish policy seems to be based on a rather ambiguous discourse of proconcentration recently (since the mid-1990s) and a more pro-dispersion slightly longer ago. This reflects (and is reflected by) the urban morphology in both countries. If we bear in mind the two dimensions of sprawl discussed in Section 2, we can observe that both countries have a large urban uptake, but the shape of that in Flanders is more dispersed than in the Netherlands (Figure 1). According to the EEA, Belgium and the Netherlands are the two countries with the highest share of urban land in the European Union. In addition, Belgium has the highest level of dispersion of urban use; the Netherlands is fourth in that ranking (Henning et al., 2016, p. 58).

\subsubsection{The Netherlands}

More than anything, Dutch urban discourse can be qualified as pro-polycentric, which is somewhere between pro-dispersion and pro-concentration. In an attempt to measure polycentricity, Meijers (2008) ranks the Netherlands as the most polycentric country in the EU. In his definition, a national urban system is more polycentric when the urban areas (e.g., the functional urban areas) are more equally sized, distributed more evenly across the nation's territory and when their accessibil- 


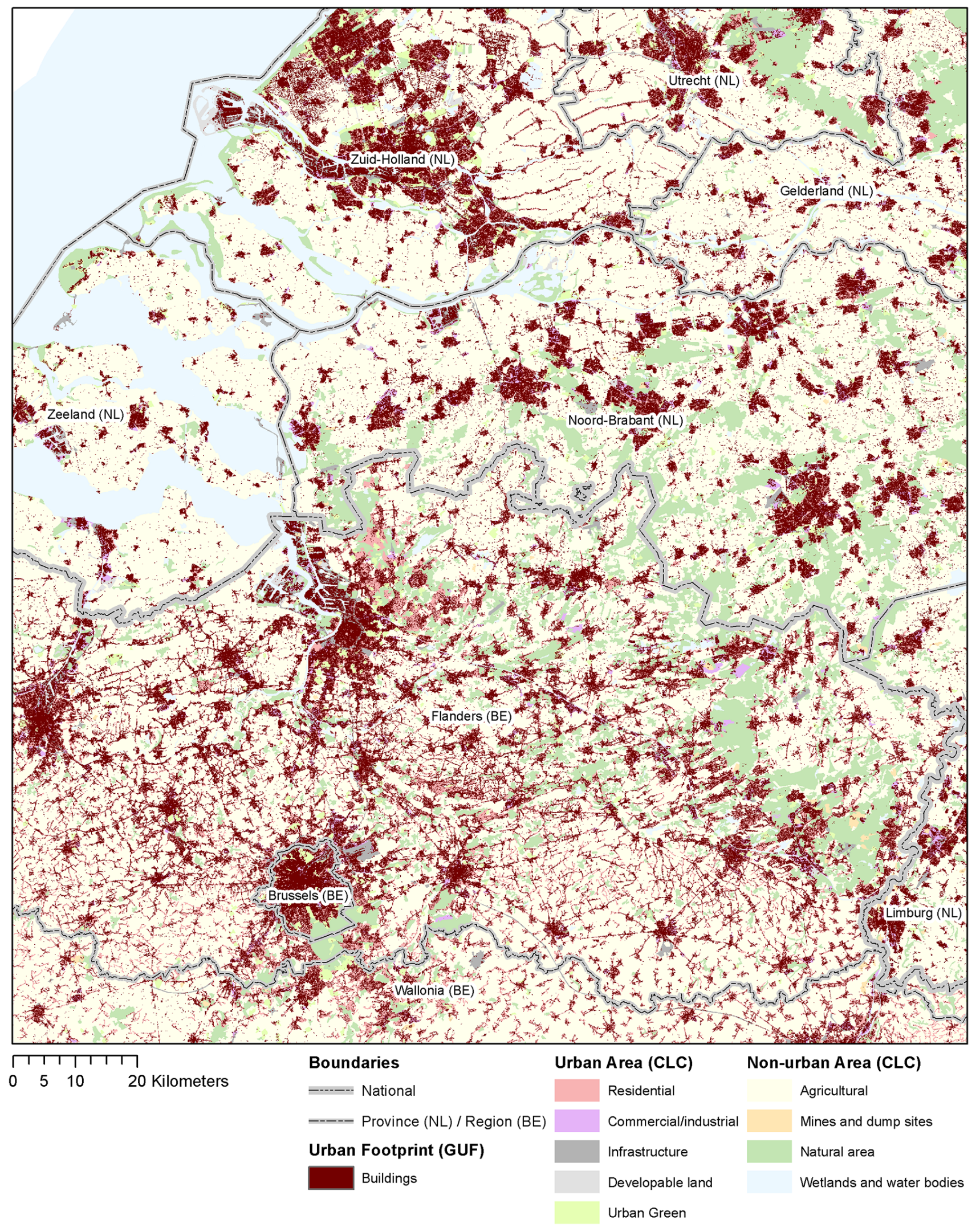

Figure 1. Urban morphology in Flanders and the Netherlands. Figure composed using Corine Land Cover 2012 (by Copernicus), Global Urban Footprint 2012 (by the DLR) and EuroGeographics.

ity is more equal. The polycentric urban structure was enabled and reproduced by post-WWII (national) urban discourse aimed at separating cities from each other and cities from the countryside (Faludi \& van der Valk, 1994). We mention three subsequent policies that have taken this view and (re)produced a polycentric discourse and a 
ditto urban structure, namely (1) national buffer zones, (2) new towns and (3) compact cities.

The first policy is that of national buffer zones (Rijksbufferzones), a concept first coined in 1958 and incorporated into the first national plan, which was adopted in 1960. Those were zones between the major cities in the west of the Netherlands (Amsterdam, Rotterdam, The Hague and Utrecht) that were to remain green and agricultural in order for the cities to remain separate entities and not be swallowed by post-war urban expansion. The committee that prepared the national plan was very clear about the purpose of those buffer zones:

If one lets development have its course, then one loses one of the major advantages of the Randstad over foreign conurbations: the spatially separate cities of a convenient size. Therefore, it is necessary, where possible, to keep a dividing zone between the cities of $4 \mathrm{~km}$ free from development. (VROM, 2008, p. 13 , authors' translation)

In 1963, those zones were safeguarded in local land-use plans (bestemmingsplannen). Later, other regions outside the Randstad area followed. In 2012, the buffer zone policy was abolished (at least at the national level) by the national spatial strategy (the SVIR) that was then adopted.

Another national policy that reproduced the polycentric discourse is the new-town policy (groeikernenbeleid). In post-war Holland, there was great urban pressure, but at the same time, there was the desire to keep some areas free from development (e.g., the national buffer zones) and to distribute housing and economic activities. This policy aim was referred to as "bundled deconcentration," which was the key of the second national plan of 1966: In other words, sprawl, but in a consolidated and coordinated way (van der Cammen \& de Klerk, 2003). The new-town policy was established in 1972 (and completed in the mid-1980s) and was considered part of the implementation of bundled deconcentration. Unlike the villes nouvelles around Paris, the Dutch new towns were not aimed at strengthening a major metropolis. They were deliberately planned as satellite towns, at some distance from the major cities, in an attempt to distribute the population and relieve the cities (Reijndorp, Bijlsma, Nio, \& van der Wouden, 2012).

The fourth national plan (Vino) came in 1988, with an addendum in 1990 (Vinex). The aim of bundled deconcentration was replaced by the compact city concept. The central government focused on strengthening the bigger cities by stimulating housing development in or attached to the existing urban fabric, on which it agreed with regions in covenants (in return for subsidies). These developments have become known as Vinex sites. However, in implementing the compact city policy, the central government was not very selective. Smaller cities and new towns, such as Leidschendam, Zoetermeer and Houten, got their own Vinex site within municipal bound- aries (Leidschenveen, Oosterheem and Castellum respectively; see van der Wouden, 2016). Also, investment policies in the existing urban centres (stedelijke knooppunten) moved gradually from stimulating only the bigger cities to a much less selective group of as many as thirteen urban regions (Zoete, 1997).

In short, Dutch (national) urban policy has, for a long time, been concerned with separating cities and distributing urban activities. Rather than a fragmented and haphazard kind of urban sprawl, a coordinated and consolidated, but nevertheless "sprawled," form thereof was (implicitly) advocated and implemented.

\subsubsection{Flanders}

The Flemish region is characterised by extensive urban sprawl: $33 \%$ of its territory is now "settlement area" (Pisman, 2018) that is used for housing, industrial and commercial purposes, health care, education, nursing infrastructure, roads and rail networks, recreation, etc. Important historical reasons for Flanders's extensive sprawl are the favourable physical (soil and water) conditions and the anti-urban housing policy in the first half of the 20th century by the Catholic and Socialist Parties promoting residential development in rural areas through subsidies and the layout of an intricate public transport system (de Block, 2011; Dehaene, 2013; Smets, 1986). Both political parties agreed on the advantages of housing working-class families in rural dwellings with gardens in comparison to the alcoholism and other risks associated with housing them in cities (De Decker, 2011).

This discourse has intensified since the emergence of the land-use planning and building permit system in the 1960s-1970s. Legally binding land-use plans were developed at the Belgian/national level and defined the land use of every square meter in the entire territory of Belgium. Moreover, inspired by an overarching modernist pro-growth discourse, land was allocated very generously for residential, industrial and commercial purposes in cities as well as in smaller villages, settlements and in linear narrow zones (lintbebouwing) along many roads. Since these "national" land-use plans were only gradually replaced by new land-use plans, the impact of this generous planning exercise is noticeable even today, more than 40 years after the approval of the "national" land-use plans: 40,000 hectares of the allocated residential area is not yet developed today and cannot be eliminated either without financial compensation to the holders of the development rights.

A serious shift in the strategic planning discourse resulted in the approval of the first strategic planning document for the region of Flanders in 1997 (Albrechts, 1999; Ministerie van de Vlaamse Gemeenschap, 1997). One of the main measures of the Spatial Structure Plan for Flanders, with its overall vision of Flanders, "open and urban," was the containment of future urban growth through the definition in land-use plans of boundaries around the major and regional cities. This 
concept of deconcentrated bundling-see the similarity with the concept of bundled deconcentration in the Netherlands - takes the existing urban sprawl in Flanders as a fact but tries to cluster new developments in cities and villages. Despite this clear pro-urban and antidispersion discourse, the political consensus was missing at the time to push it through in every detail of the document. The Spatial Structure Plan for Flanders is still valid today, more than 20 years after its approval. Since 2010, the Flemish government is busy preparing a new strategic planning document which tries to introduce the ambition to reduce the daily growth of settlement area gradually, from six to seven acres today to zero in 2040. This ambition, popularly known as the "concrete stop" (betonstop) discourse, was loudly announced in the media but has not yet been implemented. In anticipation thereof, building activity has increased recently with an opposite effect on land take.

\subsection{Institutions}

The conceptual framework we suggest to assess the relation between government-created institutions and urban sprawl refers to the active, passive or persuasive position of governments. To reiterate: active government provision of (1) infrastructure or public goods or (2) land for private goods; passive regulation of land use through (1) location-specific or (2) more generic rules; and persuasion through (1) taxes or (2) subsidies in order to incentivise land use.

\subsubsection{Active Provision of Infrastructure/Public Goods}

Urban sprawl can only take place if enabled by public infrastructure provision, either proactively or retroactively. As already described, the layout of a dense public transport and road network in the first half of the twentieth century was an important historical driver behind urban sprawl in Flanders. Moreover, dispersed new residential development in unsustainable locations has urged regional and local governments to invest seriously in the provision of public goods such as public transport, energy and water supply and sewage infrastructure. Residential development evokes the provision of infrastructure and public goods rather than vice versa (Vermeiren et al., 2018).

This is quite different from new urban developments in the Netherlands that are commonly designed in a consolidated way, which allows for infrastructure to be developed alongside and in conjunction with it (Buitelaar \& Bregman, 2016). New towns such as Zoetermeer, Nieuwegein and Leidschendam were developed along major motorways and provided with train or light-rail connections to the adjacent urban centres (The Hague and Utrecht in this case). Also, the Vinex urban extension areas were facilitated by easy car access and, albeit to a lesser extent, by public transport connection to city centres (van der Wouden, 2016).

\subsubsection{Active Provision of Land for Private Development}

Local authorities can go further than only providing land for public goods. As they get involved in the development of (private) land for housing and real estate, they might affect urban extension patterns. National urban policies in the Netherlands rely heavily on implementation by municipalities, in particular on active local land policies (Needham, 1989). Around two thirds of Dutch housing is provided by active municipal land policy, that is, by local governments buying land, preparing it for construction and then selling it to an actor willing and able to construct real estate (Bregman, Karens, Buitelaar, \& de Zeeuw, 2018). Not only is active land policy used as an instrument to guide development-if governments sell land, but they are also able to impose detailed restrictions with regard to future land use-it is an additional source of public income (Buitelaar, 2010). This applies to greenfield land more than it does to brownfield sites since in case of the latter land, rents are much smaller or non-existent. Therefore, urban extension is financially appealing to local governments, albeit not in a fragmented and haphazard way. Due to geological circumstances-much of the country lies at low altitude and has a weak soil-developing land is costly and therefore favours doing so in large quantities and in a coordinated way in order to achieve "economies of scale" (Buitelaar \& Witte, 2011). The Dutch active land policy thus provides an incentive for consolidated sprawl.

In Flanders, the real estate market is almost completely privately organised: $84 \%$ of the land that is still available for residential development is in private hands and is mainly developed at the initiative of individuals and households (Loris, 2009). Private developers are rather small in size and often locally based. Municipalities are not buying and selling land actively, their role is quite passive. The non-existence of a tradition in active land policy by governments and the abundance of allocated and yet-to-develop residential area in the land-use plans do not help prevent nor stimulate urban sprawl: Actors act within the limits set by the landuse plans. Furthermore, the will of local governments to contain cities is limited since a large part of their revenues is based on income taxes.

\subsubsection{Passive Location-Specific Regulation}

The stock of allocated residential area in the Flemish "national" land-use plans consists of existing residential areas as well as potential residential expansion areas. The existing areas were located specifically in cities and village centres but were also conceived in the 1970s as linear zones along roads between villages. This contributed to the emergence of more than 13,000 kilometres of what is now called residential "ribbon development" (Pisman, 2018). Residential expansion areas were planned in villages and smaller settlements. Summarized one could say that, already in the 1970s, the Belgian gov- 
ernment had planted the seeds for future haphazard urban sprawl. Most municipalities have added new residential expansion areas or have introduced low-density rules and large distances between buildings through local landuse plans and ordinances (Renard, 1995). Instead of controlling urban sprawl, location-specific regulations at the national/Flemish and local level have promoted urban sprawl.

In the Dutch context, location-specific rules, enacted by municipalities, provinces and the national government have also contributed to the polycentric urban structure. Earlier, the national buffer zones had already been mentioned. They are an example of locationspecific rules that had a large impact on the coming about of the Dutch polycentric urban structure. Also, other restrictive national and provincial rules (most notably growth controls around urban nodes) have been used to keep cities relatively small and green space relatively empty, hence contributing to creating and reproducing the polycentric structure (Faludi \& van der Valk, 1994).

\subsubsection{Passive Location-Generic Regulation}

In both countries, there are many local generic rules that stimulate sprawl, such as parking ordinances with high parking norms, general and restrictive height standards, high minimal widths between buildings, etc. However, there were and are some additional general spatiallyfocused rules in Flanders that increase sprawl which are absent in the Netherlands.

The best-known rule in Flanders was introduced together with the land use plans in the 1970s: the so-called "fill-in rule" (opvulregel). This rule allowed, regardless of the actual allocation in the land-use plan, to develop the land between two houses for residential purposes, as long as these two houses were no more than 75 metres apart and on the same side of the street. In practice, houses on the other side of the street were also considered and the distance was measured with an elastic band (i.e., in practice, more distances of over 75 meters were also considered; Renard, 1995). Around the turn of the century, the Flemish government introduced a more nuanced version, which translates as the rule of the "waiting façade" (wachtgevelregel). This rule allows new homes to be built against blind waiting façades, regardless of the allocation in the land-use plan. At the same time, the Flemish government created, in the "national" law, a new apparatus of fundamental building rights that allow former agricultural constructions to be converted, renovated or rebuilt for residential purposes. Although situated in agricultural area on the land-use plans next to the already generous location-specific regulations, these location-generic rules at national and local level stimulate urban sprawl.

\subsubsection{Persuasion through Taxes}

In the Netherlands, all properties are taxed in the same way. The property tax is a locally determined percentage of the property value, which has to be determined on the basis of standard valuation rules. Logically, let alone empirically, there does not seem to be a causal relation, in any direction, between the property-tax system and urban development (and sprawl).

The Flemish government taxes private property on an annual basis. As these property taxes are based on outdated theoretical rental values, referring to a no longer existing difference in comfort between urban mansions and rural sheds, they are higher for dwellings in cities than for dwellings in rural municipalities. As a consequence, it is fiscally more attractive to build or renovate houses in the countryside.

\subsubsection{Persuasion through Subsidies}

As previously mentioned, the system of subsidies in the first half of the 20th century has favoured and accelerated urban sprawl in Flanders. In recent decades, such subsidies were absent. In the Netherlands, until recent years when public austerity entered the urban-policy domain, decades of urban-renewal programs and accompanying budgets and subsidies were in place to invest in existing (often deprived) urban areas (e.g., stadsverniewing, stedelijke vernieuwing, aandachtswijken, krachtwijken, etc.; see Verheul, Daamen, Heurkens, Hobma, \& Vriends, 2017). At the same time, there were also large sums of money available for the development of greenfield land. The implementation of the earlier mentioned new-town policy (the 1970s and 1980s) and compact city policy (in the 1990s) was made possible by national location subsidies (Faludi \& van der Valk, 1994; Jókövi, Boon, \& Filius, 2006). It shows the dual attitude towards sprawl: dispersion but in a consolidated way.

\section{Discussion}

The aim of this article has been to put forward a conceptual framework on government discourses and institutions that enables the analysis of their impact on urban development. Based on the institutional literature, the framework distinguishes between discourses and various categories of institutions. It helps compare territories with different institutional contexts. In this article, we used this framework to assess Flanders and the Netherlands, two neighbours with similar physical conditions yet substantially distinct urban structures and institutional arrangements. By making discourses and various categories of institutions explicit, the framework helps focus on urban sprawl issues that matter when comparing countries or regions. That is why the framework is used in this article and ought to be considered as a list of topics to guide discursive and institutional analyses of policy documents and laws and to manage semistructured qualitative interviews or focus group discussions with experts and stakeholders on the topic of urban sprawl. The kind of result that emerges from this type of framework for comparative research is explanatory to 
the familiar, more quantitative research that measures urban sprawl, its causes and its effects. It complements the latter research with much-needed insights that allow for policy recommendations.

This article confirms Moroni and Minola's (2019, p. 110) statement that "it is difficult to sustain the thesis that sprawl is the result of deregulation or a lack of planning....It has been more probably caused (also) by inadequate regulation and planning." This is probably most apparent in Flanders, which is the more "sprawled" of the two territories. Until quite recently, the Flemish government adopted a clear pro-dispersion urban discourse and institutions to back it up. Since those institutions were quite passive in approach, governments mainly relied on the control of private initiatives by landowners through a system of permits based on generous zoning plans and generic building laws. It explains the much dispersed, non-systematic development of urban sprawl in Flanders. However, in the Netherlands, the polycentric urban discourse, and the policies to support it, have produced a more "sprawled" urban pattern than would have been the case if all efforts-such as in Francehad been directed towards creating and maintaining a large metropolis.

\section{Conclusion}

The article shows the close connection between the urban discourse and the various institutions governments introduce. There is coherence between the public urban policy aims and the means governments employ to implement those policies. This arguably has to do with an observation Lindblom (1959) made long ago: "Ends and means are simultaneously chosen." The means support the various degrees and forms of the desired sprawl in Flanders and the Netherlands, although in the case of Flanders there has been some divergence between discourse and institutions in recent years.

Since 2010, the Flemish government has been preparing a new strategic planning document which tries to introduce the ambition to reduce the daily growth of urbanised area gradually, from six to seven acres today to zero in 2040 (Vlaamse overheid, 2018). This ambition, popularly known as the "concrete stop" (betonstop) discourse, has been loudly announced in the media but fails to be formally approved. As a consequence, the actual building activity has increased with an opposite effect on land take. Where government discourse has become proconcentration, institutions are still supporting the preceding dispersive discourse.

In the Netherlands, apparently, the need to stop further urban sprawl seems non-existent. The draft National Strategy on Spatial Planning and the Environment (Government of the Netherlands, 2019) suggests that "the further expansion of windmill parks, seaports, airports, brainports, greenports, digital infrastructure and so on, is perfectly thinkable because this will happen in a sustainable and circular way" (Leinfelder, 2019, p. 30).
The fact that government contributes to and coproduces sprawl implies that they also own the key to urban containment, one could argue. However, "the weight of the past is an impediment since the policies...are strongly path-dependent" (De Decker, 2011, p. 1648). In Flanders, the government seeks change and has adopted a discourse of urban concentration since the mid-1990s. At the same time, it faces vested rights and interests that favour a reproduction of the prevalent scattered urban pattern. Not only institutions filter our future behaviour; the urban pattern itself also gives rise to path dependency. In the Netherlands, there are debates about the lack of a central and large metropolis and the need for working towards one. But urban planning cannot work from scratch. There is no tabula rasa: There is an existing urban structure that has evolved over centuries. It is arguably most effective and efficient to retrofit that structure and make it more sustainable than to try to replace it with a new structure altogether.

This article has been an exercise in international comparative research, the central topic of this thematic issue. Referring to the modes of comparative learning in Van Assche, Beunen, and Verweij (2020) in this journal, it has focused mainly on learning from the past and learning from other places. The value of learning lies not so much in borrowing best practices from other countries, in the form of policy transfer or institutional transplantation. Primarily, international comparisons help to contextualise and understand one's own national practices. Van Assche et al. (2020) state that self-observation and observations of others have to be sharpened simultaneously to enable learning through comparison. Without that, people tend to take urban morphologies, policy discourses, institutional arrangements, and other social constructions for granted, as if there is no alternative. International comparisons allow for avoiding essentialist ontologies. Urban sprawl is not inevitable; it is humanly constructed, in some cases almost designed, as are the various forms that its morphology, discourse and institutions may take across the globe.

\section{Acknowledgments}

The authors would like to express their gratitude to four anonymous reviewers for their valuable suggestions and to Maarten van Schie for composing the map on urban morphology (Figure 1).

\section{Conflict of Interests}

The authors declare no conflict of interests.

\section{References}

Albrechts, L. (1999). Planners as initiators and catalysts of change. The new structure plan for Flanders. European Planning Studies, 7(5), 587-603.

Alexander, E. R. (2001). Why planning vs. markets is 
an oxymoron: Asking the right question. Planning \& Markets, 4(1), 1-6.

Alexander, E. R. (2005). Institutional transformation and planning: From institutionalization theory to institutional design. Planning Theory, 3, 209-223.

Anthony, J. (2004). Do state growth management regulations reduce sprawl? Urban Affairs Review, 39(3), 376-397.

Arts, B., van Tatenhove, J., \& Leroy, P. (2000). Policy arrangements. In J. van Tatenhove, B. Arts, \& P. Leroy (Eds.), Political modernisation and the environment. The renewal of environmental policy arrangements (pp. 53-69). Dordrecht: Kluwer.

Bregman, A., Karens, J., Buitelaar, E., \& de Zeeuw, F. (2018). Gebiedsontwikkeling in een nieuwe realiteit [Territorial development in a new reality]. The Hague: Instituut voor Bouwrecht.

Brueckner, J. (2000). Urban sprawl: Diagnosis and remedies. International Regional Science Review, 23(2), 160-171.

Buitelaar, E. (2003). Neither market nor government. Comparing the performance of user rights regimes. Town Planning Review, 74(3), 315-330.

Buitelaar, E. (2010). Cracks in the myth: Challenges to land policy in the Netherlands. Journal of Economic and Social Geography, 101(3), 349-356.

Buitelaar, E., \& Bregman, A. (2016). Dutch land development institutions in the face of crisis. Trembling pillars in the planners' paradise.' European Planning Studies, 24(7), 1281-1294.

Buitelaar, E., Lagendijk, A., \& Jacobs, W. (2007). A theory of institutional change: Illustrated by Dutch cityregions and Dutch land policy. Environment and Planning $A, 39,891-908$.

Buitelaar, E., \& Witte, P. (2011). Financiering van gebiedsontwikkeling: een empirische analyse van grondexploitaties [Financing of territorial development: An empirical analysis of land exploitations]. The Hague: PBL - Netherlands Environmental Assessment Agency.

Colsaet, A., Laurans, Y., \& Levrel, H. (2018). What drives land take and urban land expansion? A systemic review. Land Use Policy, 79, 339-349.

de Block, G. (2011). Engineering the territory. Technology, space and society in 19th and 20th century Belgium (Unpublished Doctoral dissertation). $\mathrm{KU}$ Leuven-Faculty of Engineering Science, Leuven, Belgium.

De Decker, P. (2011). Understanding housing sprawl: The case of Flanders, Belgium. Environment and Planning A, 43(7), 1634-1654.

Dehaene, M. (2013). Gardening in the urban field. Gent: A\&S Books.

Ewing, R. (1997). Is Los Angeles-style sprawl desirable? Journal of the American Planning Association, 63(1), 107-126.

Ewing, R., \& Hamidi, S. (2015). Compactness versus sprawl: A review of recent evidence from the
United States. Journal of Planning Literature, 30(4), 413-432.

Ewing, R., Pendall, R., \& Chen, D. (2002). Measuring sprawl and its impacts. Washington, DC: Smart Growth America.

Faludi, A., \& van der Valk, A. (1994). Rule and order. Dutch planning doctrine in the twentieth century. Dordrecht: Kluwer Academic Publishers.

Frenkel, A., \& Ashkenazi, M. (2008). Measuring urban sprawl: How can we deal with it? Environment and Planning B, 35(1), 56-79.

Galster, G., Hanson, R., Ratcliffe, M., Wolman, H., Coleman, S., \& Freihage, J. (2001). Wrestling sprawl to the ground: Defining and measuring an elusive concept. Housing Policy Debate, 12(4), 681-717.

Gheysen, M., Scheerlinck, K., \& van Daele, E. (2017). Opposing oppositions. All city/all land. Magazine on Urbanism, 26, 62-67.

Gordon, P., \& Richardson, H. (2000). Critiquing sprawl's critics. Policy Analysis, 2000(365), 1-18.

Government of the Netherlands. (2019). Draft national strategy on spatial planning and the environment. The Hague: Ministry of the Interior and Kingdom Relations. Retrieved from https://www.ontwerpnovi. $\mathrm{nl} /$ translations+draft+novi+and+sea/handler downloadfiles. ashx?idnv=1419958

Hajer, M. (1995). The politics of environmental discourse: Ecological modernization and the policy press. Oxford: Oxford University Press.

Hall, P., \& Taylor, R. (1996). Political science and the three new institutionalisms. Political Studies, 64, 936-957.

Hamidi, S., Ewing, R., Preuss, I., \& Dodds, A. (2015). Measuring sprawl and its impacts: An update. Journal of Planning Education and Research, 35(1), 35-50.

Henning, E., Jaeger, J., Soukup, T., Orlitová, E., Schwick, C., \& Kienast, F. (2016). Urban sprawl in Europe. Copenhagen: European Environment Agency.

Jaeger, J., Bertiller, R., Schwick, C., \& Kienast, F. (2010). Suitability criteria for measures of urban sprawl. Ecological Indicators, 10, 397-406.

Jókövi, M., Boon, C., \& Filius, F. (2006). Woningbouw ten tijde van de Vinex [Housing development in the era of the Vinex]. The Hague and Rotterdam: Ruimtelijk Planbureau and NAi Uitgevers.

Kahn, M. E. (2001). Does sprawl reduce the black/white housing consumption gap? Housing Policy Debate, 12(1), 77-86.

Leinfelder, H. (2019). Where is the guiding planning tradition? In P. Gerretsen (Ed.), Take on the future (pp. 30-31). Rotterdam: Deltametropool Association.

Lewyn, M. E. (2005). How overregulation creates sprawl (even in a city without zoning?). Wayne Law Review, 50, 1172-1207.

Lindblom, C. (1959). The science of "muddling through." Public Administration Review, 19(2), 79-88.

Lindblom, C. (2001). The market system: What it is, how it works, and what to make of it. New Haven, CT: Yale University Press. 
Loris, I. (2009). Particulier bezit meeste bouwgrond [Private actor possesses most of the building land]. Ruimte, 1(4), 50-53.

March, J., \& Olsen, J. (1989). Rediscovering institutions: The organizational basis of politics. New York, NY: The Free Press.

Meijers, E. (2008). Measuring polycentricity and its promises. European Planning Studies, 16(9), 1313-1323.

Ministerie van de Vlaamse Gemeenschap. (1997). Ruimtelijk Structuurplan Vlaanderen [Spatial structure plan Flanders]. Brussels: Ministerie van de Vlaamse Gemeenschap.

Montgomery, M. (2008). The urban transformation of the developing world. Science, 319(5864), 761-764.

Moroni, S., \& Minola, L. (2019). Unnatural sprawl: Reconsidering public responsibility of suburban development in Italy, and the desirability and possibility of changing the rules of the game. Land Use Policy, 86, 104-112.

Morriss, A., \& Meiners, R. (2000). The destructive role of land use planning. Tulane Environmental Law Journal, 14, 95-137.

Nechyba, T., \& Walsh, R. (2004). Urban sprawl. Journal of Economic Perspectives, 18(4), 177-200.

Needham, B. (1989). Strategic planning and the shape of the Netherlands through foreign eyes: But do appearances deceive? Built Environment, 15(1), 11-16.

Needham, B., Buitelaar, E., \& Hartmann, T. (2018). Planning, law and economics. The rules we make for using land. London: Routledge.

Neutelings, W. J. (1991). Willem Jan Neutelings Architect. Rotterdam: Maaskant Foundation-010 Publishers.

North, D. (1990). Institutions, institutional change and economic performance. New York, NY: Cambridge University Press.

Oueslati, W., Alvanides, S., \& Garrod, G. (2015). Determinants of urban sprawl in European cities. Urban Studies, 52(9), 1594-1614.

Pendall, R. (1999). Do land-use controls cause sprawl? Environment and Planning B, 26(4), 555-571.

Pisman, A. (2018). Kernbegrippen [Main notions]. In A. Pisman, S. Vanacker, P. Willems, G. Engelen, \& L. Poelmans (Eds.), Ruimterapport Vlaanderen: Een ruimtelijke analyse van Vlaanderen [Spatial report Flanders: A spatial analysis of Flanders] (pp. 13-56). Brussels: Vlaamse overheid.

Reijndorp, A., Bijlsma, L., Nio, I., \& van der Wouden, R. (2012). Nieuwe steden in de Randstad. Verstedelijking en suburbaniteit [New cities in the Randstad. Urbanisation and suburbanity]. The Hague: PBLNetherlands Environmental Assessment Agency.

Renard, P. (1995). Wat kan ik voor u doen? Ruimtelijke wanorde in Belgie: een hypotheek op onze toekomst [What can I do for you? Spatial disorder in Belgium: A mortgage on our future]. Antwerp: Icarus.

Resnik, D. (2010). Urban sprawl, smart growth, and deliberative democracy. American Journal Public Health,
100(10), 1852-1856.

Schmidt, V. (2010). Taking ideas and discourse seriously: Explaining change through discursive institutionalism as the fourth 'new institutionalism.' European Political Science Review, 2(1), 1-25.

Sieverts, T. (1999). Zwischenstadt: Zwischen Ort und Welt, Raum und Ziet, Stadt und Land [City in between: Between place and world, space and time, city and countryside]. Braunschweig: Vieweg.

Smets, M. (1986). La Belgique ou la banlieue radieuse [Belgium or the radial suburbanity]. Brussels: Fondation de l'Architecture.

Squires, G. (Ed.). (2002). Urban sprawl, causes, consequences and policy responses. Washington, DC: The Urban Institute Press.

Tennekes, J., Harbers, A., \& Buitelaar, E. (2015). The institutional origins of morphological differences between the Netherlands, Flanders and North RhineWestphalia. European Planning Studies, 23(11), 2165-2183.

Uhel, R. (2006). Urban sprawl in Europe, the ignored challenge. Copenhagen: European Environment Agency.

Van Assche, K., Beunen, R., \& Verweij, S. (2020). Comparative planning research, learning, and governance: The benefits and limitations of learning policy by comparison. Urban Planning, 5(1), 11-21.

van der Cammen, H., \& de Klerk, L. (2003). Ruimtelijke ordening. Van grachtengordel tot Vinex-wijk [Spatial planning. From canal belt to Vinex-neighborhood]. Amsterdam: Het Spectrum.

van der Wouden, R. (2016). Succes of falen? Een halve eeuw verstedelijkingsbeleid in Nederland [Success or failure? A half century of urbanisation policy in the Netherlands]. Ruimte \& Maatschappij, 8(1), 8-26.

Verheul, W., Daamen, T., Heurkens, E., Hobma, F., \& Vriends, R. (2017). Gebiedstransformaties. Ruimte voor durf en diversiteit [Territorial transformations. Space for nerve and diversity]. Delft: TU Delft.

Vermeiren, K., Poelmans, L., Engelen, G., Broeckx, S., Beckx, C., de Nocker, L., \& van Dyck, K. (2018). Monetariseren van de impact van urban sprawl in Vlaanderen [Monetizing the impact of urban sprawl in Flanders]. Brussels: Vlaamse overheid.

Vigano, P., Arnsperiger, C., Barcelloni Corte, M., CogatoLanza, E., \& Cavalieri, C. (2017). Rethinking urban form: Switzerland as a "horizontal metropolis." Urban Planning, 2(1), 88-99.

Vlaamse overheid. (2018). Strategische visie van het Beleidsplan Ruimte Vlaanderen [Strategic vision of the policy document Space Flanders]. Brussels: Vlaamse overheid.

VROM. (2008). 50 jaar Rijksbufferzones: Jubileumboek [50 years of national buffer zones: Jubilee book]. The Hague: Ministry of VROM.

Zoete, P. (1997). Stedelijke knooppunten: Virtueel beleid voor een virtuele werkelijkheid? [Urban nodes: Virtual policy for a virtual reality?]. Utrecht: Utrecht University. 


\section{About the Authors}

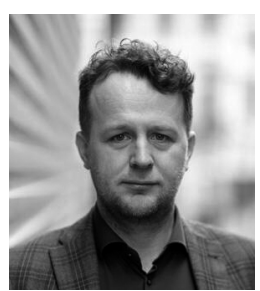

Edwin Buitelaar is Professor of Land and Real Estate Development at Utrecht University and a Senior Researcher at the PBL Netherlands Environmental Assessment Agency. His work focuses on the coming about of urban development, with a particular focus on housing, commercial real estate, planning law, land policy, land-use planning and the financial side of development. Recent publications include Planning, Law and Economics (2018, with Barrie Needham and Thomas Hartmann) and Cities, Economic Inequality and Justice (2017, with Anet Weterings and Roderik Ponds).

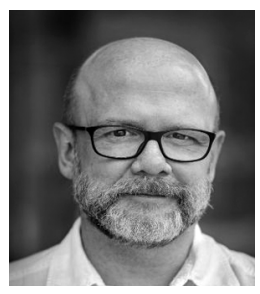

Hans Leinfelder is Associate Professor in the Master Program in Urbanism and Spatial Planning at the Faculty of Architecture of KU Leuven, Belgium. He is also a member of the P.PUL research group within the Department of Architecture. He has commuted between academic research at Ghent University (1992-1996 and 2002-2010) and KU Leuven (2014-now), and policymaking in the Flemish Government (1996-2002 and 2010-2014). His academic research focuses on substantive and instrumental aspects of planning policy, with a preference for planning challenges in peri-urban open spaces and the translation of societal challenges into planning policy instruments. 